\title{
YOUTH UNEMPLOYMENT AND ITS MAIN CAUSES IN LATGALE REGION
}

\section{Anda ZVAIGZNE'1, Inese SAULĀJA², Aija ČERPINSKA ${ }^{3}$}

${ }^{1}$ Dr.oec., leading researcher at the Research Institute for Regional Studies and associate professor at the Faculty of Economics and Management,

Rezekne Higher Education Institution, Rezekne, Latvia, e-mail: andazvaigzne@inbox.lv, phone: +371 26307669,

2 Mg.oec., lecturer at the Faculty of Economics and Social Development, Latvia University of Agriculture, Jelgava, Latvia, e-mail: inese.saulaja@llu.lv, phone: +371 63025170, 3 Mg.soc.sc., lecturer at the Faculty of Economics and Management, Rezekne Higher Education Institution, Rezekne, Latvia, e-mail: aija@ru.lv, phone: +371 26468837

\begin{abstract}
Youth unemployment is an urgent problem in the European Union, as well as in the regions of Latvia. The research aim is to examine the trends and the causes of youth unemployment in Latgale region and to make proposals for improving the situation.

Youth unemployment is a significant problem in Latvia, as unemployed youngsters make up $13.1 \%$ of the total number of unemployed in the country, while in Latgale region the number of unemployed young people aged of 15-24 amounted to 8.8\% of the total number of unemployed in 2014.

The novelty of the present research is that the known unemployment causes for youths (aged of 15-24) were defined more precisely and new causes of youth unemployment in Latgale region were revealed. In Latgale, there are various causes of youth unemployment, such as lack of professional skills, poor preparedness for the labour market, lack of foreign language skills (especially the Russian language) as well as lack of social competences (cooperation or work in a team, communication, skills to take responsibility and lack of self-confidence).
\end{abstract}

Keywords: youth unemployment; causes; employment JEL code: $J 000$

\section{Introduction}

The future of Latvia's regions and the entire European Union depends, to a great extent, on human capital, especially young people who begin working or soon are going to start their careers.

Youth unemployment is an urgent problem in the European Union, as well as in the regions of Latvia. Increasing the employment of young people and reducing unemployment in Latvia's regions decreases migration, improves the economic situation and raises the wellbeing and standard of living of every youngster.

Employment problems in Latvia and elsewhere in the world have been researched by a number of authors: Niklass M. (2013), Saulāja I., 
Rasnača L., Krūzmētra Ž., Bite D. (2007); Saulaja I., Rasnača L. (2008); Rasnaca L., Kruzmetra Z., Bite D., Saulaja I. (2008); Adamonienè R., Čiutienè R. (2010); Zvaigzne A. (2012); Zvaigzne A., Saulaja I., Zeiferte D. (2013); Zvaigzne A., Saulāja I., Čerpinska A (2013); Zvaigzne A., Saulāja I. (2013); Zvaigzne A., Saulaja I., Zeiferte D. (2014) et al.

In recent years in Latvia, youth unemployment and employment problems were examined from various perspectives. Most research studies on youth employment mainly focus on identifying factors and conditions that promote or hinder the integration of young people into the labour market. Researchers explain the problem of youngsters' integration into the labour market by the lack of human capital in them, i.e., the lack of work experience, knowledge and skills. Researchers also point that the social environment and the network of social contacts and its quality (i.e., social capital) characteristic of a certain social group greatly influences youngsters' choice of careers and work opportunities. Finally, a number of researchers justify the problem of youngsters' integration into the labour market by various conditions young people cannot control or influence, for example, the overall economic situation, poverty, high unemployment, social exclusion, the closed labour market or its segmentation and discrimination by employers and the public. Researchers also mention a number of other factors - the need to walk long distances to school, emigration, low achievers, health and adverse effects of your friends - who can influence young people's studying and relationships with teachers (Niklass M., 2013; Kraitone et al, 2006; Pigozne T., 2014).

When structural unemployment prevails in the country, it is important to improve labour market professional preparation: taking into account market and personal interests, to increase the variety of proposed training programs. Career design specialists have to consult youngsters in territorial jobcentres for these purposes. Young man, who attained the profession meeting his interests and simultaneously marketable in the labour market, will be able to find or to create own workplace. (Adamonienè R., Čiutienė R., 2010)

The conditions and causes of youth unemployment can change; therefore it is necessary to update information on them. By identifying the causes and seeking to avoid them, it is possible to reduce youth unemployment in Latgale region.

The research aim is to examine the trends and the causes of youth unemployment in Latgale region. To achieve the aim, the following research tasks were set:

1. To examine information on the trends in youth unemployment in Latgale region; 
2. To identify the key causes of youth unemployment in Latgale region.

Research hypothesis: Youth unemployment in the region of Latgale has various causes.

The novelty of the present research is that the known youth unemployment causes (aged of 15-24) were defined more precisely and new causes of youth unemployment in Latgale region were revealed.

To perform the tasks set in the present research, a number of research methods were used: the monographic and descriptive methods as well as analysis and synthesis, the graphic method and statistical analysis - correlation analysis - a sociological method - discussion in small focus groups (4-5 participants in a group). Eight focus group discussions were conducted for the present research.

The present research is based on various scientific publications, publicly available documents, information available in databases of the Republic of Latvia, discussions of a focus group, and other sources.

\section{Trends in youth unemployment in Latgale region}

State Employment Agency (hereinafter - the SEA) data of 2014 show that youth unemployment is an urgent problem in Latvia, as 7522 individuals or $13.1 \%$ of the total number of the unemployed in the country were young people, while in Latgale region 1721 unemployed individuals aged of $15-24$ or $8.8 \%$ of the total number of unemployed were youngsters. In 2014 compared with 2010 in Latvia and in Latgale region, the number of unemployed youngsters declined, by $68 \%$ and 64\%, respectively (Figure 1 ), because, according to the CSB, the number of economically active individuals (aged of 15-64) decreased by 6.6\% in the same period.

In 2014, in Latgale, the majority of young people - 66\% or 139 individuals - were granted the status of unemployed, as they terminated their labour relationships. In 2014 compared with 2010 in Latgale, the number of such youngsters declined by $19 \%$ or 40 individuals.

It is likely that youth in Latgale are not interested in working, as new vacant jobs of low qualification with low social guarantees and a low wage are registered in greater numbers in this region than elsewhere in Latvia.

Such jobs are as follows: stokers, sales clerks, unskilled workers, tailors and others. In Latgale, there are job vacancies, the demand for which is greater than the supply, for instance, medical employees, education employees, psychologists and others. 


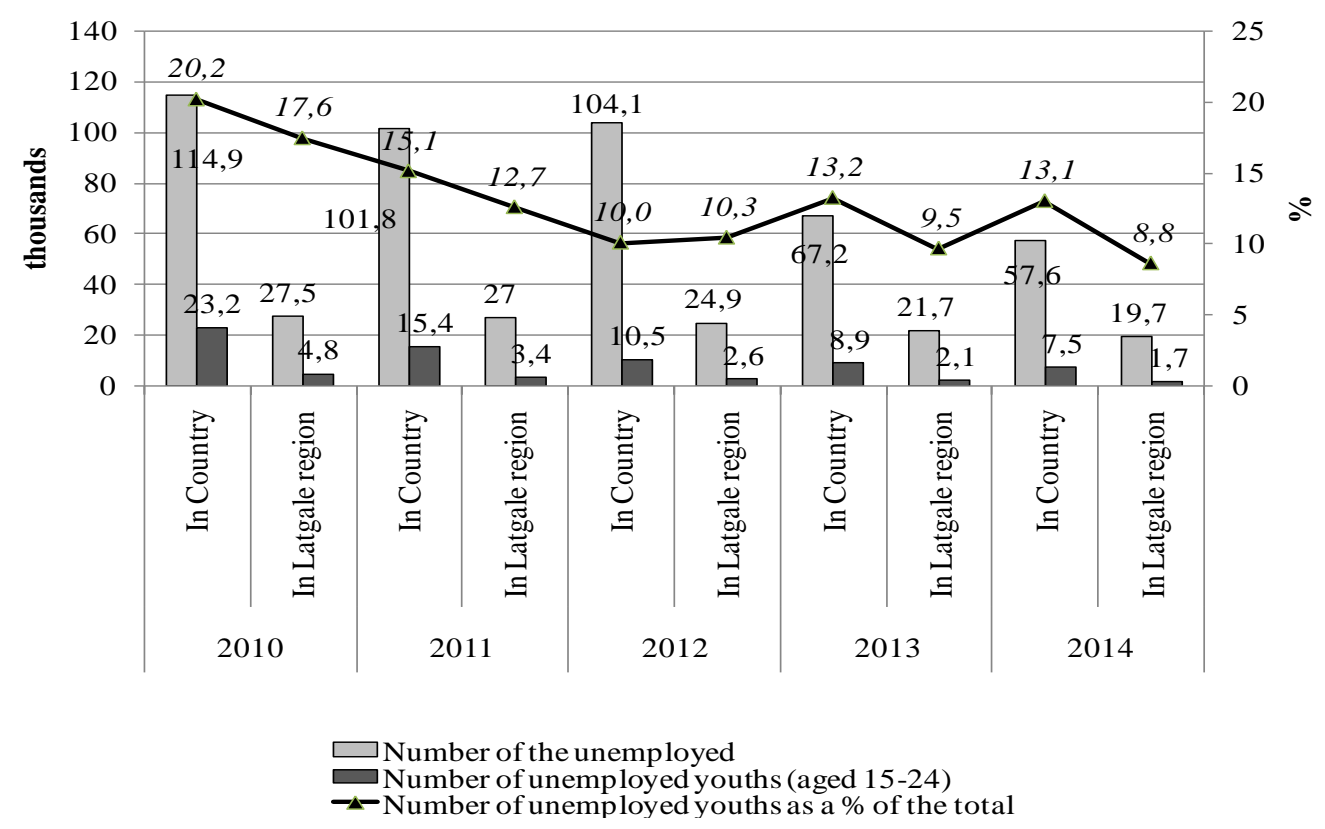

Fig.1 Youth unemployment in Latvia and Latgale region in the period 2010-2014

(Source: SEA data)

As shown in Figure 2, in 2014, 25 youngsters or $11.8 \%$ of the total were granted the status of unemployed after their childcare leave, while 20 youngsters or $9.5 \%$ got this status upon graduating from an education institution, 1 youngster or $0.5 \%$ was granted the status of unemployed after release from imprisonment and 26 people or $12.3 \%$ had other reasons.

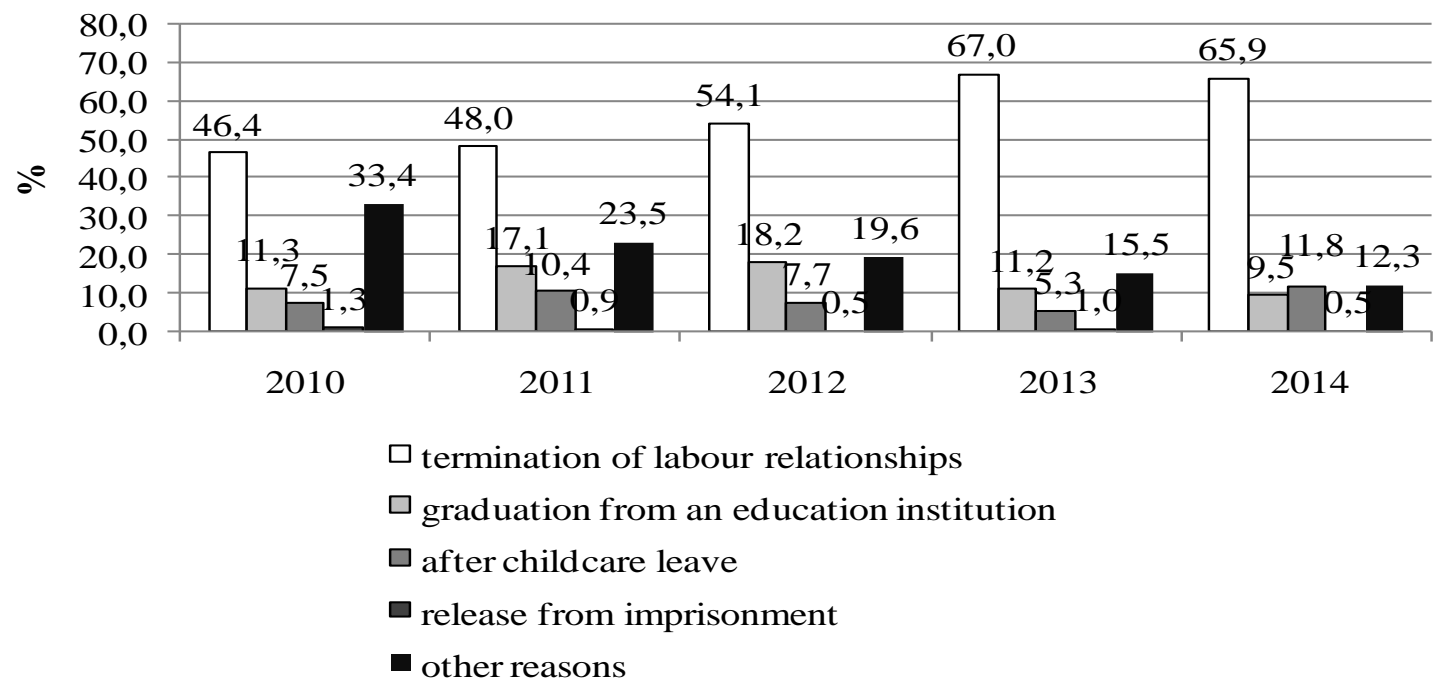

Fig.2 Percentage distribution of the reasons of granting the status of unemployed to young people in the period 2010-2014 (end of the year) in Latgale

(Source: SEA data) 
According to the SEA, in 2014 in Latgale region, 105 youngsters or $53 \%$ (Figure 3) of the total were removed from the records of unemployment because they did not fulfil their duties of unemployed person.

The number of such unemployed young people decreased by $59 \%$ or 154 individuals in 2014 compared with 2010.

In 2014, 81 youngsters or $40 \%$ of the total lost their status of unemployed, as they got a job. However, in 2014 compared with 2010, the number of such young people who got a job and lost the status of unemployed decreased by $17 \%$ or 17 individuals.

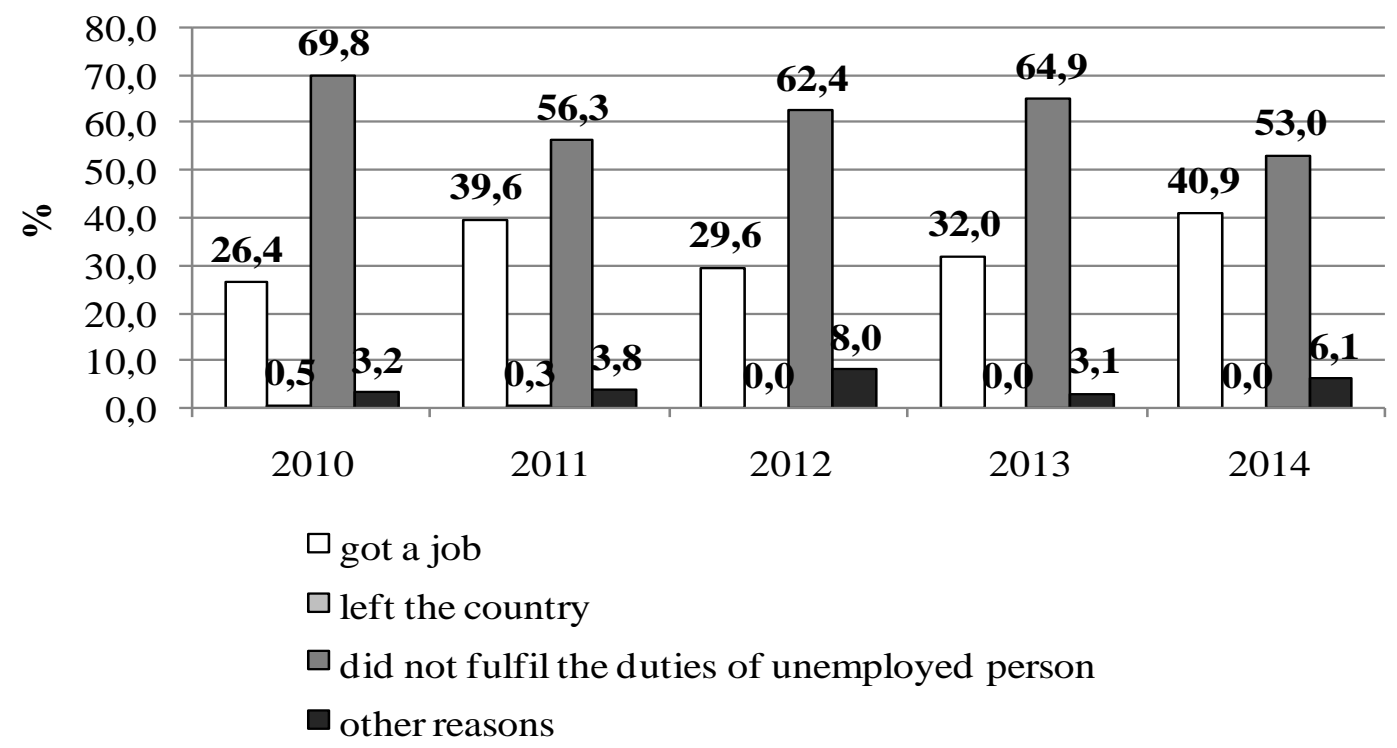

Fig.3 Percentage distribution of the reasons of removing youngsters from the records of unemployment in the period 2010-2014

(end of the year) in Latgale

(Source: SEA data)

According to the SEA, in 2010 in Latgale region, the highest proportion of youngsters - 2900 or $60 \%$ of the total - had general education; professional education was acquired by 1359 unemployed young people or $28 \%$ of the total. Yet, in 2014 compared with 2010, the number of unemployed young people with general education decreased by $83 \%$ or 2415 individuals, with professional education - by $57 \%$ or 773 and with higher education -by $62 \%$ or 219 individuals (Figure 4 ). 


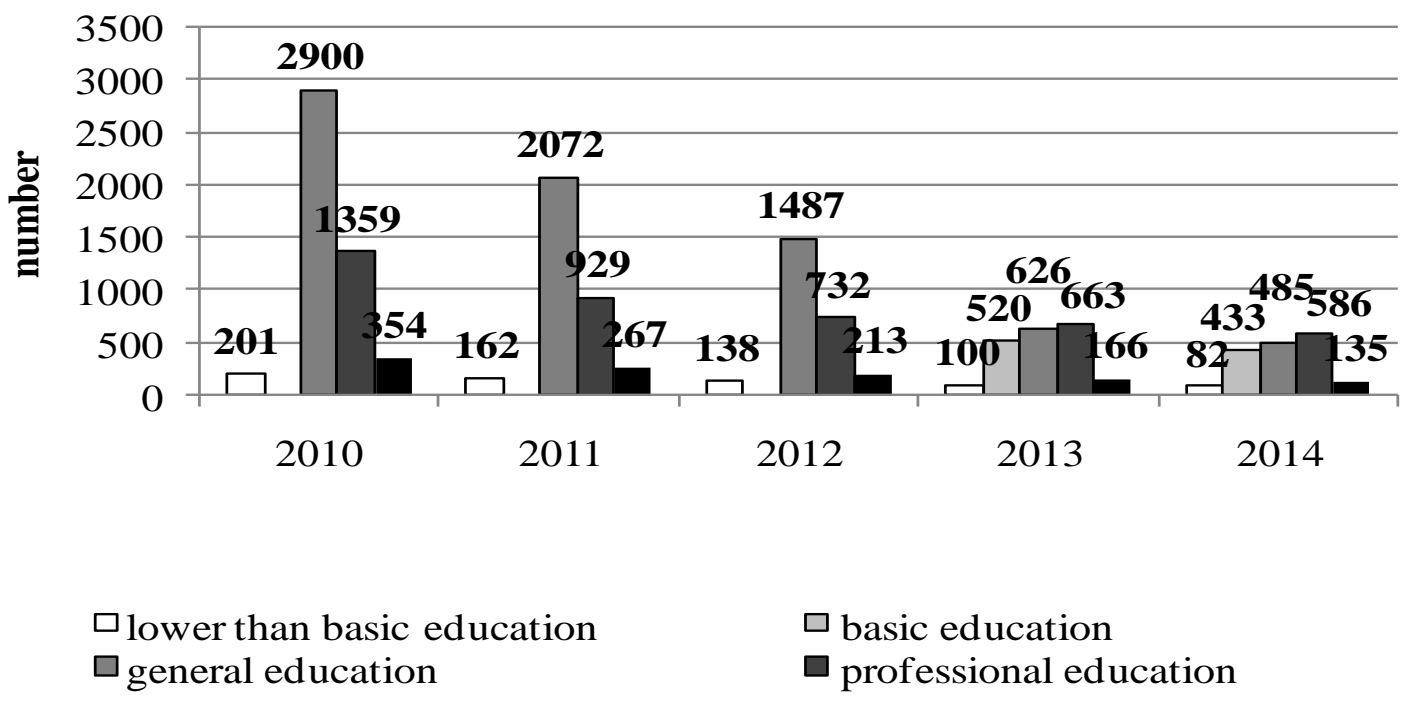

Fig.4 Distribution of unemployed youngsters by education level in the period 2010-2014 in Latgale (Source: SEA data)

A correlation indicates an association between two or among several variables (i.e., if one variable changes, the other also changes) (Arhipova I., Balina S., 2003). A correlation analysis performed in the research shows that there is a medium strong correlation between the number of youngsters who get a job and their education level: $r=0.62$ for higher education; $r=0.59$ for professional education; $r=0.64$ for general education and $r=0.60$ for lower than basic education.

The longer the unemployment period is, the greater influence it makes on young people: declines in self-confidence and health, stress, etc.

The SEA data show that in Latgale, among the unemployed, youngsters are those who find a job faster than others. In 2014 compared with 2011, the number of young people being unemployed for more than 3 years decreased by $12 \%$ or 8 individuals (Figure 5). Further, the research will focus on the causes of youth unemployment in Latgale region. 


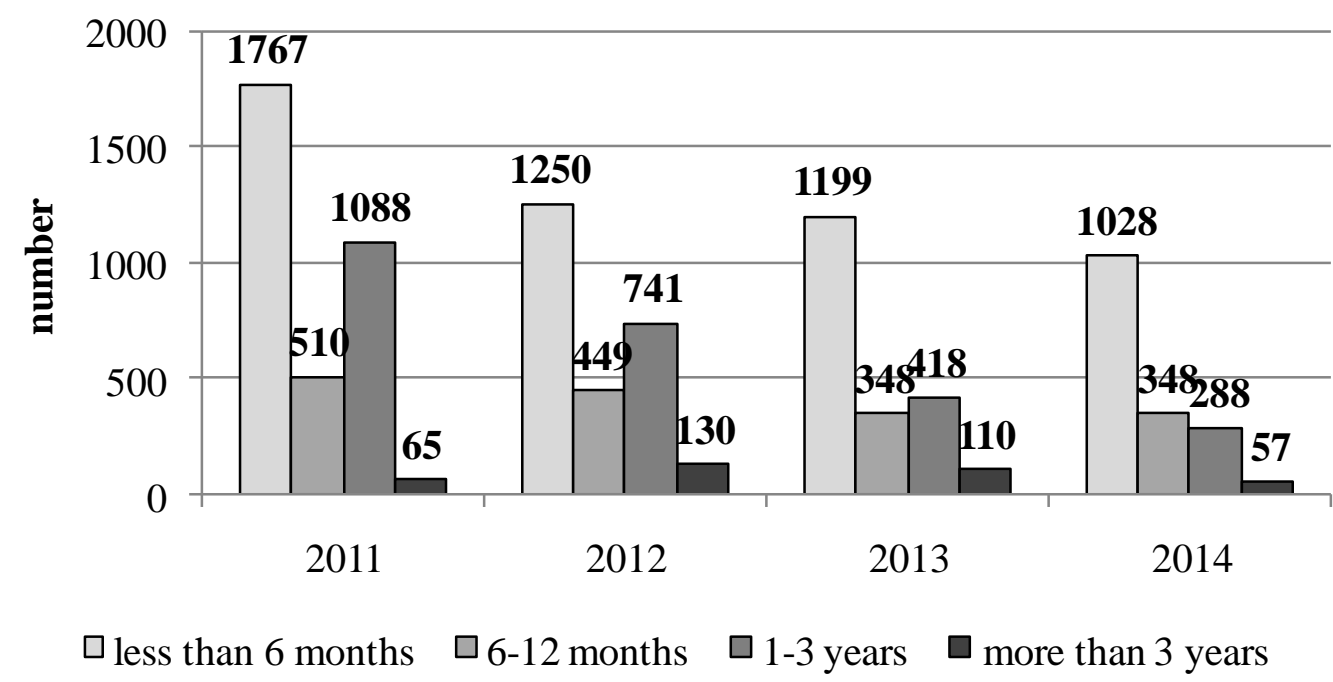

Fig. 5 Distribution of unemployed youngsters by length of unemployment in the period 2011-2014 in Latgale

(Source: SEA data)

\section{Causes of youth unemployment in Latgale region}

Discussions in small focus groups were conducted to identify the causes of youth unemployment in Latgale region. Focus group discussions are useful for in-depth examinations of opinions and reactions in a certain target population as well as for finding new creative solutions. This method allows seeing the behaviour, attitude and emotions of respondents, understanding and analysing the motives and arguments of respondents, receiving feedback and creating new ideas. A similar method is a small focus group discussion (4-5 participants in the group), which is often more effective, as everyone can express their opinion and young people are less stressful (Fokusa grupu ..., s.a.).

Eight small focus group discussions were conducted for the present research. The criteria of selection of focus group participants were as follows:

- $\quad$ place of residence - Latgale region;

- young people who do not study and do not work;

- $\quad$ aged of 15-24.

The total number of youngsters who participated in the focus group discussions amounted to 38. The key youth unemployment causes in Latgale region were identified after summarising the opinions expressed by the eight focus groups.

The focus group discussions revealed that young people most often terminated their labour relationship already during their trial period. Youngsters were often dismissed because the employees who had been doing the job before restored their labour relationship as well as because 
the youngsters were late for their job due to long working hours. Therefore, to reduce youth unemployment in Latgale region, it is important to stimulate flexible employment by offering part-time jobs, seasonal jobs, work at home, etc.

The discussions revealed that there had been instances where enterprises where youngsters worked were liquidated as well as employers did not pay high enough wages and therefore the young people were forced to leave their job. The discussions showed that young people have large ambitions and they wishea high wage and are highly selective regarding their job. Sometimes youngsters were easily involved in various employer manipulations, for instance, they were given a job for a trial period and then no wage was paid and they were discharged. Also, sometimes no labour contract was concluded and the contract was incorrect. It would be important to explain youngsters at school (in senior grades) what a labour contract is and what a role it plays in labour relationships.

With youth unemployment increasing in Latgale region, the number of recipients of unemployment benefits is also rising and therefore extra funding from the government budget is necessary. High unemployment, especially among young people, can cause various risks - unrest, apathy and despair -the disappointed society contributes to it owing to the lack of job opportunities.

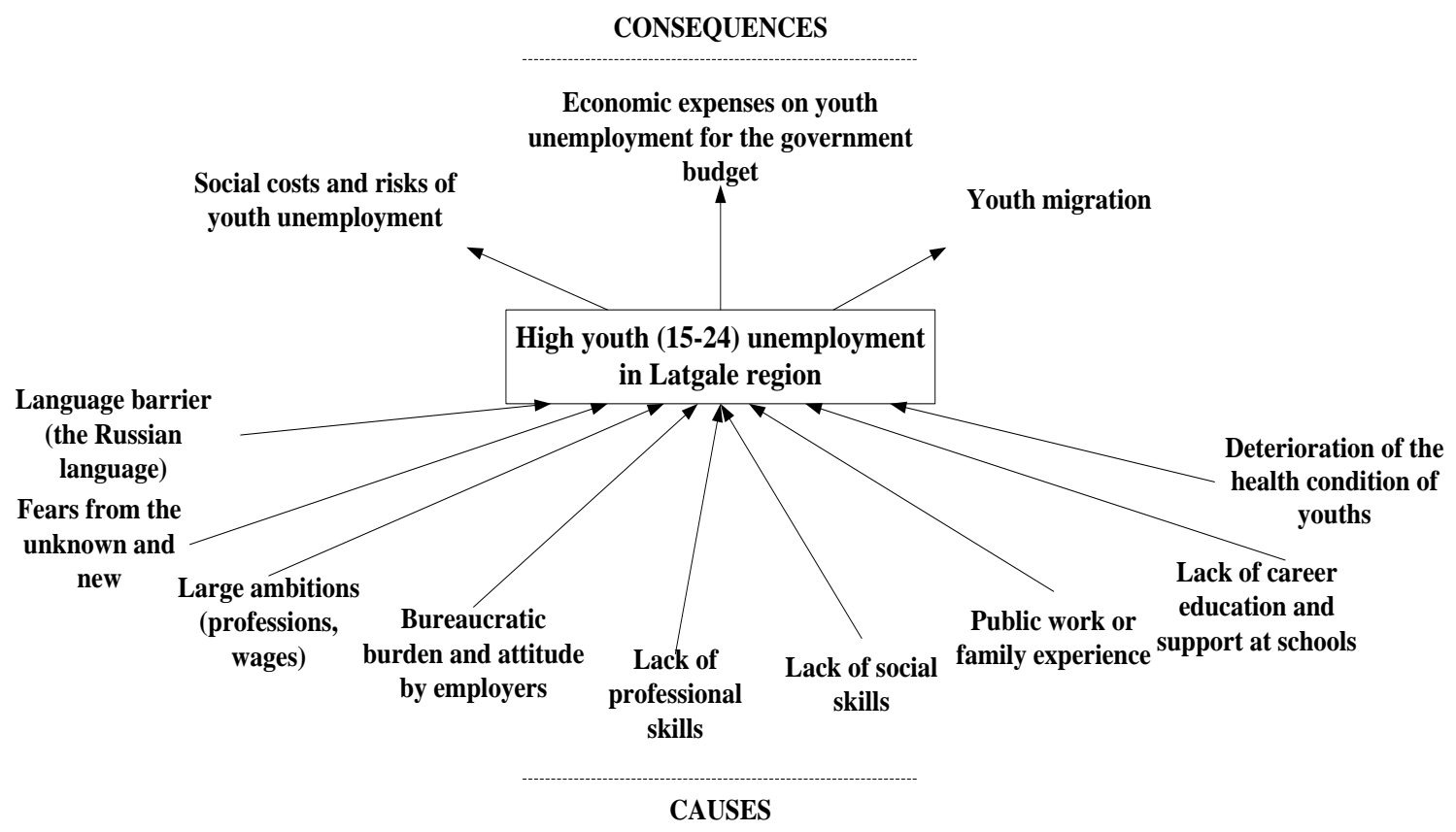

Fig.6 Scheme for the cause-consequence relationship for youth unemployment in Latgale (Source: author's construction) 
The increasing youth migration (from Latgale region) caused significant loss of human capital. This loss often relates to the insufficient employment of young people and/or the insufficient use of their talents or skills.

During the course of the research, the key causes of youth unemployment in Latgale region were discovered (Figure 6): lack of professional skills, poor preparedness for the labour market, lack of foreign language skills (especially the Russian language) as well as lack of social competences (cooperation or work in a team, communication, skills to take responsibility and the lack of self-confidence). Youngsters lack public work or family experience as well.

\section{Conclusions and proposals}

The number of young people who are granted the status of unemployed because of the termination of their labour relationships is increasing fast. A positive trend is the fact that the number of young people who are granted the status of unemployed upon graduating from an education institution is decreasings. In recent years, the number of young people who were removed from the records of unemployment because they got a job, even though unsteadily, has a tendency to increase.

There is a medium strong correlation between the number of unemployed youngsters who get a job and their education level: $r=0.62$ for higher education; $r=0.59$ for professional education; $r=0.64$ for general education and $r=0.60$ for lower than basic education.

The number of young people who are unemployed for 3 and more years is decreasing; yet, over the last two years, the number of youths unemployed for 6-12 months has been constant.

The focus group discussions revealed that high unemployment among young people can cause various risks - unrest, apathy and despair - the disappointed society contributes to it owing to the lack of job opportunities. Latgale region may suffer from the loss of human resources, as young people migrate from this region owing to high unemployment (not only to foreign countries but also to cities and the capital city). The research hypothesis was proved and the focus group discussions revealed the key causes of youth unemployment in Latgale region: lack of professional skills, poor preparedness for the labour market, lack of foreign language skills, etc. Young people lack public work or family experience as well. The focus group discussions revealed that sometimes youngsters are easily involved in various employer manipulations, for instance, they are given a job for a trial period and then no wage is paid and they are dismissed. Also, sometimes no labour 
contract is concluded or the contract is incorrect. It would be important to explain young people at school (in senior grades) what a labour contract is and what a role it plays in labour relationships.

To reduce youth unemployment in Latgale region, it is important to stimulate flexible employment by offering part-time jobs, seasonal jobs, work at home, etc.

\section{References}

1. NIKLASS M. (2013) Jauniešu ar zemu izglītību iekḷaušanās darba tirgū Latvijā (Integration of Youths with Low Education into the Labour Market in Latvia): Retrieved March 12, 2015, from http://www.szf.lu.lv/fileadmin/user_upload/ szf_faili/Petnieciba/promocijas_darbi/Mareks\%20Niklass_2013.pdf

2. Latgalē vairāk nekā pusei bezdarbnieku darba nav ilgstoši (More than Half of the Unemployed in Latgale have no Job for a Long Time ) Retrieved March 13, 2015, from http://financenet.tvnet.lv/zinas/552188-latgale_vairak_neka_pusei_ bezdarbnieku_darba_nav_ilgstosi

3. Fokusa grupu diskusijas metode (Focus Group Discussion Method): Retrieved March 12, 2015, from http://aptaujucentrs.com/lv/page/pakalpojumi/centrsdiskusijam-un-testiem/fokusa-grupu-diskusijas

4. Bezdarba rādītāji Latvijā un Latgalē 2010.-2014.gadam: NVA dati (Unemployment Indicators in Latvia and Latgale in 2010-2014: SEA data)

5. ADAMONIENÉ R., ČIUTIENÉ R. (2010) Problems and Possibilities of Youth Integration to Labour Market. Ekonomika ir Vadyba: 2010. 15, ISSN 1822-6515, pp.343-350 Retrieved March 16, 2015, from http://internet.ktu.lt/lt/mokslas/ zurnalai/ekovad/15/1822-6515-2010-343.pdf

6. KRAITONE, DŽOANNA \& CITI. (2006). Pamatizglītību nepabeigušie skolēni. Network of Education Policy Centres \& Providus. Pieejams tiešsaistē: http://www.providus.lv/public/27035.html

7. PİGOZNE T. (2014) Pieaugušo izglītības resursi jauniešu bezdarba mazināšanai IZM projekta „Eiropas programmas īstenošana pieaugušo izglītības jomā” (Adult Education Resources for Reducing Youth Unemployment within the MoES Project „Implementation of the European Programme in the Field of Adult Education"), 2014

8. ARHIPOVA, I., BALINA, S. (2003). Statistika ekonomika. Risinajumi ar SPSS un Microsoft Excel (Statistics in Economics. Solutions by SPSS and Microsoft Excel). Riga: Datorzinibu centrs, p. 352.

9. Iedzīvotāji pēc ekonomiskās aktivitātes un dzimuma (Central Statistical Bureau. Population by Labour Status and Sex) Retrieved March 17, 2015, from (http://data.csb.gov.lv/pxweb/lv/Sociala/Sociala_ikgad_nodarb/NB0010.px/t able/tableViewLayout1/?rxid=cdcb978c-22b0-416a-aacc-aa650d3e2ce0

10. Nodarbinātības valsts aǵentūra (State Employment Agency) Retrieved March 10, 2015, from http://www.nva.gov.lv/index.php?cid=6\&mid=67

11. Youth employment in EU, Retrieved March 26, 2015, from: http://ec.europa.eu/ social/main.jsp?catId=1036 


\title{
JAUNIEŠU BEZDARBS UN GALVENIE CĒLON̦I LATGALES REĢIONĀ
}

\author{
Anda ZVAIGZNE ${ }^{1}$, Inese SAULĀJA ${ }^{2}$, Aija ČERPINSKA ${ }^{3}$
}

${ }^{1}$ Dr.oec., Rēzeknes Augstskolas, Reǵionālistikas zinātniskā institūta vadošā pētniece, Rēzekne, Latvija

Ekonomikas un pārvaldības fakultātes asociētā profesore,

2 Mg.oec., Latvijas Lauksaimniecības universitātes, Ekonomikas un sabiedrības attīstības fakultātes lektore, Jelgava, Latvija

${ }^{3}$ Mag.soc.sc., Rēzeknes Augstskolas, Ekonomikas un pārvaldības fakultātes lektore, Rēzekne, Latvija

\section{Kopsavilkums}

Aktuāla Eiropas Savienības, t.sk. Latvijas reǵionu problēma ir jauniešu bezdarbs. Pētījuma mērḳis ir izpētīt jauniešu bezdarba tendences un cēloṇus Latgales reǵionā un sniegt priekšlikumus situācijas uzlabošanai.

Jauniešu bezdarbs ir aktuāla problēma, jo Latvijā 2014.gadā 13,1 \% no bezdarbnieku kopskaita bija jaunieši bezdarbnieki, bet Latgalē 8,8 \% jaunieši bezdarbnieki vecuma grupā 15 - 24 gadi.

Pētījuma novitāte ir precizēti zināmie un atklāti jauni jauniešu (15-24) bezdarba cēloṇi Latgales reǵionā. Latgalē jauniešu bezdarbam ir ļoti dažādi cēloṇi, tādi kā profesionālo zināšanu trūkums, vispārējā jauniešu sagatavotība darba tirgum, valodu zināšanu trūkums (sevišksi krievu valoda), kā arī sociālo kompetenču trūkums (sadarbība jeb komandas darbs, komunikācija, atbildības uzṇemšanās prasmes, un pārliecības trūkums).

Pētījuma mērḳis ir izpētīt jauniešu bezdarba tendences un cēloṇus Latgales reǵionā.

Strauji pieaug to jauniešu skaits, kas iegūst bezdarbnieka statusu, kā darba attiecības pārtraukuši. Samazinās to jauniešu skaits, kas iegūst bezdarbnieka statusu pēc mācību iestādes absolvēšanas. Tādējādi Latgales reǵions var ciest no cilvēkresursu zaudējumiem, jo augsta bezdarba dēl jaunieši migrē no reǵiona (ne tikai uz ārzemēm, bet arī uz lielpilsētām uz galvaspilsētu).

Lai îstenotu pētījumā izvirzìtos uzdevumus, tika izmantotas vairākas pētījumu metodes: monogrāfiski aprakstošā metode, kā arī analīzes un sintēzes, grafiskā un statistikā metode - korelācija, sociologiskās metode - mazās fokusgrupu diskusijas (4-5 dalībnieki grupā). Pētījumā tika veiktas 8 mazās fokusgrupas diskusijas. Fokusgrupas diskusijās tika atklāti galvenie cēloṇi jauniešu bezdarbam Latgales reǵionā: jauniešu profesionālo zināšanu trūkums, jauniešu sagatavotība darba tirgum, valodu zināšanu, sabiedriskā darba vai ǵimenes pieredzes trūkums u.c.

Atslēgas vārdi: jauniešu bezdarbs; cēloṇi; nodarbinātība. 